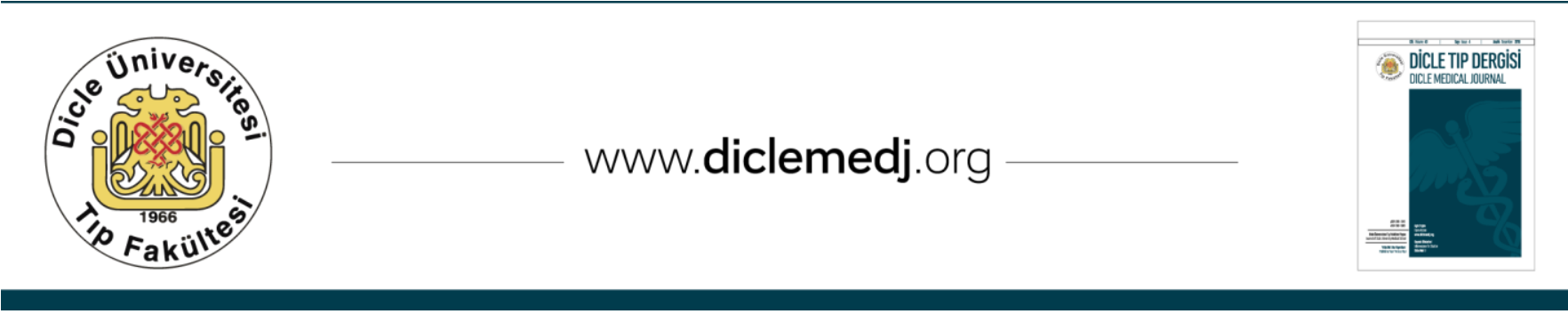

\title{
Challenges, Prognosis and Outcomes of Surgical Resection for Hepatic Alveolar Echinococcosis: A Single Centre Experience
}

\author{
Ahmet Rencuzogulları ${ }^{1}$, Ismail Soner Koltas ${ }^{2}$, Atilgan Tolga Akcam¹, Abdullah Ulku ${ }^{1}$, \\ Orcun Yalav ${ }^{1}$, Ahmet Gokhan Saritas ${ }^{1}$, Kubilay Dalc1 ${ }^{1}$, Ismail Cem Eray ${ }^{1}$ \\ 1 Cukurova University, Faculty of Medicine, Department of General Surgery, Adana, Turkey \\ 2 Cukurova University, Faculty of Medicine, Department of Parasitology, Adana, Turkey
}

Received: 21.12.2016 ; Revised: 17.02.2017 ; Accepted: 28.02.2017

\begin{abstract}
Objective: Alveolar echinococcosis (AE) is an aggressive and potentially fatal infection, which affects the liver primarily and presents as a tumor-like lesion. Outcomes associated with surgical procedures for this infection have been rarely reported. In the present study, we aimed to evaluate long-term surgical treatment outcomes associated with hepatic AE.

Methods: Between 2001 and 2013, the management and outcomes of twelve consecutive hepatic AE patients who were considered feasible for complete hepatic resection with/without metastasectomy were described. In all patients, pre-operative diagnosis of $\mathrm{AE}$ was based on clinical findings, imaging studies, and serological tests. Antibodies against antigens of Echinococcus multilocularis metacestodes were screened as specific markers for the serological diagnosis of $\mathrm{AE}$ by Western blot. The oral albendazole protocol was administered for hepatic AE patients who had complete resection.

Results: Twelve patients $(\mathrm{F} / \mathrm{M}=7 / 5)$ underwent complete resection for pathologically confirmed hepatic AE during the study period. Median follow-up was 82 (32-164) months. The most common initial symptom was abdominal pain $(n=9)$ followed by jaundice $(n=4)$. Four patients had metastasis: Brain, surrenal, splenic and colon. One patient was lost due to massive pulmonary emboli despite appropriate interventions. All other complications that emerged were treated successfully.
\end{abstract}

Conclusion: Long-term favorable outcomes can be achieved by complete surgical resection followed by chemotherapy with albendazole in advanced hepatic AE cases.

Keywords: alveolar echinococcosis; hepatic resection; Echinococcus multilocularis, tumor-like disease.

DOI: $10.5798 /$ dicletip.319757

Yazışma Adresi / Correspondence: Ahmet Rencuzogullari, Cukurova University, Faculty of Medicine, Department of General Surgery, Balcall, Sarıcam, 01330, Adana, Turkey e-mail: rencuzdr@gmail.com 


\section{Hepatik Alveolar Ekinokokkoz Cerrahisinde Zorluklar, Prognoz ve Yönetim: Tek Merkez Deneyimi}

\section{Özet}

Giriş: Alveolar ekinokokkoz (AE) primer olarak karaciğeri etkileyen ve tümör benzeri davranış gösteren, agresif ve potansiyel olarak fatal bir infeksiyondur. Bu infeksiyon için cerrahi prosedürlere ilişkin sonuçlar nadiren raporlanmıştır. Bu çalışmada hepatik AE'in cerrahi tedavisi ile ilişkili olarak uzun dönem sonuçları değerlendirmeyi amaçladık.

Yöntemler: 2001 ve 2013 yılları arasında, metastaz durumuna bakılmaksızın hepatik AE nedeniyle komplet rezeksiyon için uygun bulunan hastaların yönetimi ve sonuçları tanımlandı. Tüm hastaların preoperatif AE tanısı klinik bulgular, görüntüleme teknikleri ve serolojik testelere göre konuldu. Echinococcus multilocularis metasestod antijenine karşı oluşan antikor düzeyleri, Western Blot tekniğiyle elde edilen AE serolojik tanısı için spesifik markırlarlar olarak kullanıldı. Oral albendazol protokolü komplet rezeksiyonun yapılabildiği tüm hastalara uygulandı.

Bulgular: Çalışma periyodu boyunca patolojik olarak hepatik AE olduğu konfirme edilen 12 hastaya $(K / E=7 / 5)$ komplet rezeksiyon uygulandı. Ortanca takip süresi 82 (32-164) ay idi. En sık başlangıç semptomları karın ağrısı $(n=9)$ ve sarllık $(n=4)$ idi. Beyin, sürrenal, dalak ve kolon olmak üzere 4 hastada metastaz tespit edildi. Alınan uygun önlemlere karşın bir hastada mortalite gözlenirken, gelișen diğer komplikasyonların tamamı başarı ile tedavi edildi.

Sonuç: İleri evre hepatik AE olgularında uzun dönemdeki olumlu sonuçlar, komplet cerrahi rezeksiyon ile birlikte yapılan Albendazol uygulaması ile elde edilebilir.

Anahtar kelimeler: Alveolar ekinokokkoz, hepatik rezeksiyon, Echinococcus multilocularis, tūmör benzeri hastalık

\section{INTRODUCTION}

Alveolar echinoccosis (AE) is a parasitic zoonoses and a major public health issue in endemic areas such as Turkey. Foxes and coyotes are the definitive hosts of Echinococcus multilocularis (E. multilocularis) whereas wolves are the intermediate hosts. Recent reports have described immense concern regarding the significant increase in prevalence and distribution of E. multilocularis in red foxes, in Europe over the past 10-15 years ${ }^{1}$. The disease is aggressive and potentially fatal, since it affects the liver primarily, presents as a tumor-like lesion and metastasizes to any part of the body².

$\mathrm{AE}$ is often misdiagnosed as liver cancer and its lesions often metastasize to adjacent or distant organs. Surgery has been regarded as the first treatment modality for the potentially resectable parasitic mass based on the current treatment guidelines. Nevertheless, parasitostatic drugs have been shown to be effective as well ${ }^{1,3-6}$. Despite surgery being the gold standard for treatment, long-term outcomes associated with surgical procedures for advanced hepatic $\mathrm{AE}$ cases have been rarely reported. In the present study, we aimed to evaluate the long-term treatment outcomes associated with $\mathrm{AE}$ for patients who underwent complete hepatic resection.

\section{METHODS}

Between 2001 and 2013, hepatic AE patients who were considered feasible for resection and underwent complete resection at the Cukurova University Faculty of Medicine, Balcali Hospital, Adana, Turkey were included in the study. Patient characteristics and initial presentation features were obtained from their medical charts. Radiologic images including ultrasonography (US), triphasic tomography, magnetic resonance imaging (MRI) were retrospectively analyzed. Size and intraoperative localization of the lesions was defined based on Couinaud's anatomical classification ${ }^{7}$. Based on intraoperative findings, stage of the parasitic mass was reported according to the PNM ( $\mathrm{P}=$ parasitic 
mass in the liver, $\mathrm{N}=$ involvement of neighbouring organs, and $M=$ metastasis) staging system (18). Surgical procedures performed were documented. Postoperative complications were classified according to the Clavien-Dindo system ${ }^{8}$.

Antibodies against E. multilocularis antigens were screened as specific markers for the serological diagnosis of $\mathrm{AE}$ by Western blot (WB). Western blot serology was performed on human sera samples using the Echinococcosis WB IgG kit (LDBIO Diagnostics Lyon, France) according to the manufacturer's instructions. The protocol for hepatic AE patients who achieved complete resection was oral administration of $10 \mathrm{mg} / \mathrm{kg} /$ day albendazole in a treatment cycle of 3 weeks with 1 -week breaks for 1 year. The protocol for patients with extra-hepatic dissemination was oral administration of $10 \mathrm{mg} / \mathrm{kg} /$ day albendazole in the same treatment cycle, and these patients received life-long treatment until they experienced any adverse events. Patients were followed up every six months after discharge with serological tests by WB.

Table 1. Patient characteristics and symptoms at index admission

\begin{tabular}{ccl}
\multicolumn{3}{c}{ admission } \\
PATIENT & AGE/GENDER & SYMPTOMS (duration,years) \\
\hline 1 & $38 / \mathrm{F}$ & Jaundice,Abdominal pain (2y) \\
2 & $42 / \mathrm{M}$ & Abdominal pain,fever (5y) \\
3 & $37 / \mathrm{M}$ & Abdominal pain,nausea,jaundice (3y) \\
4 & $15 / \mathrm{M}$ & Abdominal pain ,jaundice (2y) \\
5 & $54 / \mathrm{F}$ & Abdominal pain,fever (3y) \\
6 & $52 / \mathrm{F}$ & Abdominal pain (2y) \\
7 & $65 / \mathrm{F}$ & Abdominal pain (1.5y) \\
8 & $33 / \mathrm{F}$ & Epileptic attack, headache (2y) \\
9 & $44 / \mathrm{F}$ & Abdominal pain (3y) \\
10 & $25 / \mathrm{M}$ & Nausea, itching (1y) \\
11 & $37 / \mathrm{M}$ & Fever, nausea,jaundice (2y) \\
12 & $33 / \mathrm{F}$ & Nausea,abdominal pain (4y) \\
\hline
\end{tabular}

\section{RESULTS}

Twelve patients $(\mathrm{F} / \mathrm{M}=7 / 5)$ underwent hepatic resection for hepatic $\mathrm{AE}$ during the study period. Median follow-up duration was 82 (32164) months. Patient characteristics and symptoms at index admission are presented in Table 1 . The most common initial symptom was abdominal pain in 9 of the patients followed by jaundice $(n=4)$. One particular patient was admitted to the neurosurgery clinic with the complaint of epileptic attacks and headaches (Table 1). Her brain tomography revealed a brain mass (Figure 1) for which she was operated afterwards. She was referred to the general surgery department after pathological and serological examinations of the excised lesions that were located in frontal lobes indicated AE. Further radiologic studies showed that she had a hepatic mass (Figure 2) which invaded the inferior vena cava (Figure 2).

Hepatic AE was demonstrated with US and triphasic tomography. Magnetic resonance angiography was used in five patients for differential diagnosis. Median size of the lesions was $14 \mathrm{~cm}$ (range: 6-19 cm). For all patients, completeness of hepatic resections was confirmed by pathological specimens. Distribution of patients according to the PNM staging system is given in Table 2 . Out of 12 patients, 2 patients had stage II tumors, 5 patients had stage $3 \mathrm{~A}$ tumors, 1 patient had stage $3 \mathrm{~B}$ tumor, and 4 patients had stage IV tumors. Four patients had metastasis; one brain, one surrenal, one splenic and one colon metastasis. The entire patient cohort was seropositive with $\mathrm{WB}$ screening test for $\mathrm{AE}$ prior to the surgery. The presence of both 16$\mathrm{kDa}$ and $18-\mathrm{kDa}$ bands were interpreted as a positive test for AE (Figure 3). 
Rencuzogulları A., Koltas İ.S.,Akcam A.T., Ulku A., Yalav O., Sarıtas A.G., Dalcı K., Eray İ.C.

Table 2. The size, localization, stage of the tumor, surgical interventions and complications)

\begin{tabular}{|c|c|c|c|c|c|}
\hline Patient & Size/ Localization & pTNM/Stage & Surgery & Complications & $\begin{array}{l}\text { Treatment of } \\
\text { complications }\end{array}$ \\
\hline 1 & $\begin{array}{l}15 \mathrm{~cm} / \text { Right anterior section. Sg 5, } 8 \text { and } \\
\text { spleen }\end{array}$ & $\begin{array}{l}\mathrm{P}_{3} \mathrm{~N}_{0} \mathrm{M}_{1} \\
\text { stage } 4\end{array}$ & $\mathrm{ERH}+$ splenectomy & Grade I & Conservative \\
\hline 2 & $8 \mathrm{~cm} /$ left medial section $\mathrm{Sg} 4$ & $\begin{array}{l}\mathrm{P}_{2} \mathrm{~N}_{0} \mathrm{M}_{0} \\
\text { Stage } 2\end{array}$ & ELH & Grade III-b & $\begin{array}{l}\text { R and Y hepatico- } \\
\text { jejenostomy }\end{array}$ \\
\hline 3 & $12 \mathrm{~cm} /$ left medial section. Sg 4 & $\begin{array}{l}\mathrm{P}_{3} \mathrm{~N}_{0} \mathrm{M}_{0} \\
\text { Stage } 3 \mathrm{~A}\end{array}$ & ELH, cholecystectomy & Grade V & \\
\hline 4 & $14 \mathrm{~cm} /$ left lateral section $\mathrm{Sg} 2,3$ & $\begin{array}{l}\mathrm{P}_{3} \mathrm{~N}_{0} \mathrm{M}_{0} \\
\text { Stage } 3 \mathrm{~A}\end{array}$ & ELH & Grade III-b & $\begin{array}{l}\text { Surgical primary } \\
\text { repair }\end{array}$ \\
\hline 5 & $\begin{array}{l}19 \mathrm{~cm} / \text { right posterior section } \mathrm{Sg} 6,7 \text {, } \\
\text { colon metastasis }\end{array}$ & $\begin{array}{l}\mathrm{P}_{3} \mathrm{~N}_{0} \mathrm{M}_{1} \\
\text { Stage } 4\end{array}$ & $\begin{array}{l}\text { ERH+righthemicolecto } \\
\text { my }\end{array}$ & Grade III-b & Reanastomosis \\
\hline 6 & $\begin{array}{l}6 \mathrm{~cm} / \text { left medial sectionSg } 4,5 \mathrm{~cm} / \\
\text { gastrosplenic ligament }\end{array}$ & extrahepatic & $\begin{array}{l}\mathrm{LH}+\text { Splenectomy+ mass } \\
\text { resection }\end{array}$ & - & \\
\hline 7 & $10 \mathrm{~cm} /$ right posterior section $\mathrm{Sg} 6,7$ & $\begin{array}{l}\mathrm{P}_{2} \mathrm{~N}_{0} \mathrm{M}_{0} \\
\text { Stage } 2\end{array}$ & ERH & - & \\
\hline 8 & $\begin{array}{l}19 \mathrm{~cm} / \text { right anterior section } \mathrm{Sg} 5,8, \\
\text { invasion to the } \mathrm{IVC} \text {, cerebral metastasis }\end{array}$ & $\begin{array}{l}\mathrm{P}_{4} \mathrm{~N}_{0} \mathrm{M}_{1} \\
\text { Stage } 4\end{array}$ & $\mathrm{ERH}$ & Grade IV & $\begin{array}{l}\text { Secondary } \\
\text { operation for } \\
\text { hemostasis }\end{array}$ \\
\hline 9 & $15 \mathrm{~cm} /$ right posterior section $\mathrm{Sg} 6,7$ & $\begin{array}{l}\mathrm{P}_{3} \mathrm{~N}_{0} \mathrm{M}_{0} \\
\text { Stage } 3 \mathrm{~A}\end{array}$ & $\mathrm{ERH}$ & - & \\
\hline 10 & $\begin{array}{l}14 \mathrm{~cm} / \text { right anterior section } \mathrm{Sg} 5,8 \text {, } \\
\text { hepatic lobe }\end{array}$ & $\begin{array}{l}\mathrm{P}_{3} \mathrm{~N}_{0} \mathrm{M}_{0} \\
\text { Stage } 3 \mathrm{~A}\end{array}$ & $\mathrm{ERH}$ & - & \\
\hline 11 & $17 \mathrm{~cm} /$ left medial section. Sg 4 & $\begin{array}{l}\mathrm{P}_{4} \mathrm{~N}_{0} \mathrm{M} 0 \\
\text { Stage } 3 \mathrm{~A}\end{array}$ & ELH, cholecystectomy & Grade I & Conservative \\
\hline 12 & $\begin{array}{l}12 \mathrm{~cm} / \text { right anterior section Sg 5, 8, right } \\
\text { surrenal gland }\end{array}$ & $\begin{array}{l}\mathrm{P}_{3} \mathrm{~N}_{0} \mathrm{M}_{1} \\
\text { Stage } 4\end{array}$ & $\mathrm{ERH}$ & - & \\
\hline
\end{tabular}

Sg: Segment ,ERH: Extended right hepatectomy, ELH: Extended left hepatectomy

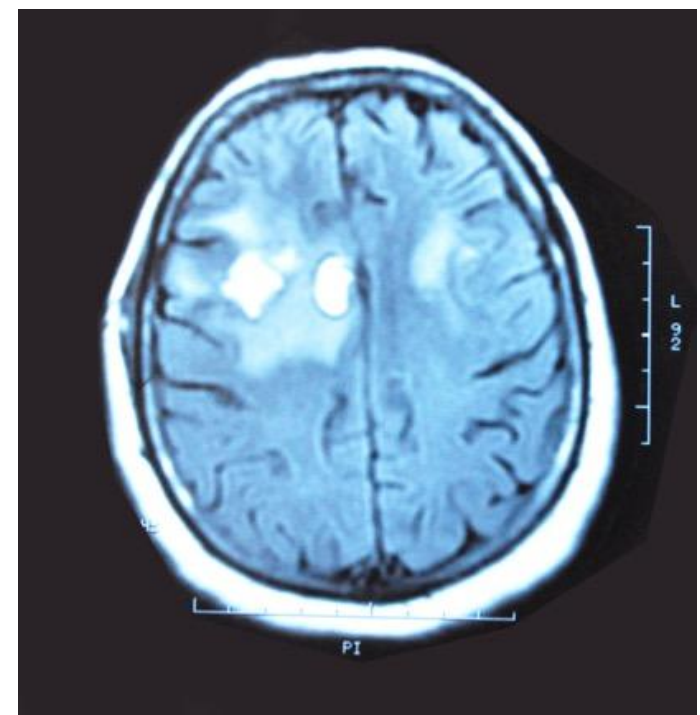

Figure 1. Well defined, contoured cystic lesions in the right frontoparietal lobe, in the parafalcine region, involving the subcortical white matter, with surrounding edema and focal edema in the white matter in the left frontal lobe.

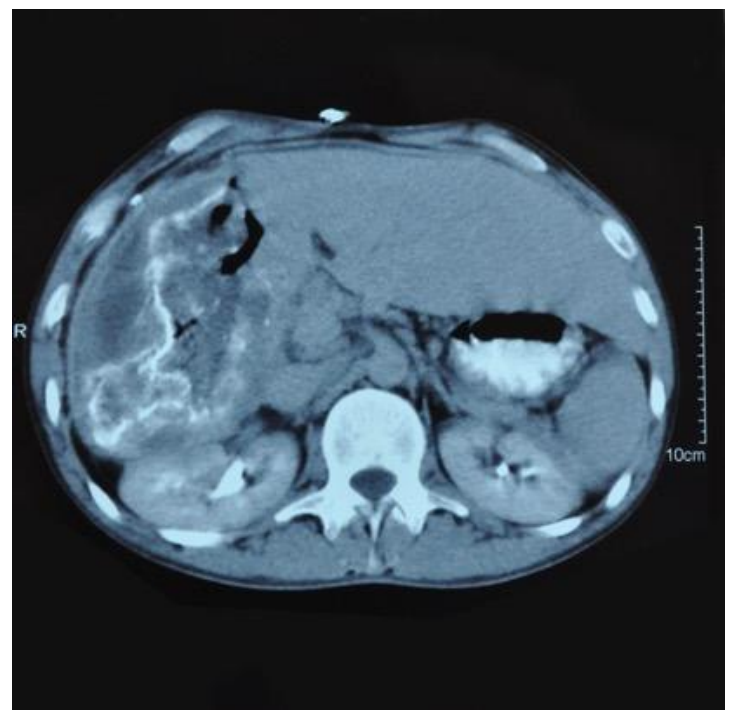

Figure 2. Wide lesion in segment 5-6 of the liver, invading vena cava inferior (arrow) with curvilinear calcifications and air pockets. 
Surgical resection was the choice of treatment in all patients. Two patients who had surrenal and splenic metastasis had splenectomy and unilateral surrenalectomy, respectively. The patient who had colonic invasion underwent a right hemicolectomy. In five patients, there were no complications during surgery or follow-up. Two patients had a minor postoperative complication [Clavien-Dindo I \& II], whereas six had major (Clavien-Dindo $\geq$ III) complications (massive ascites, biliocutaneus fistula, evisceration, leak from ileocolic anastomosis, bleeding and pulmonary emboli resulted in mortality) (Table 2). Only one patient, who had initially presented with a brain metastasis, still had WB seropositivity for AE after surgery.

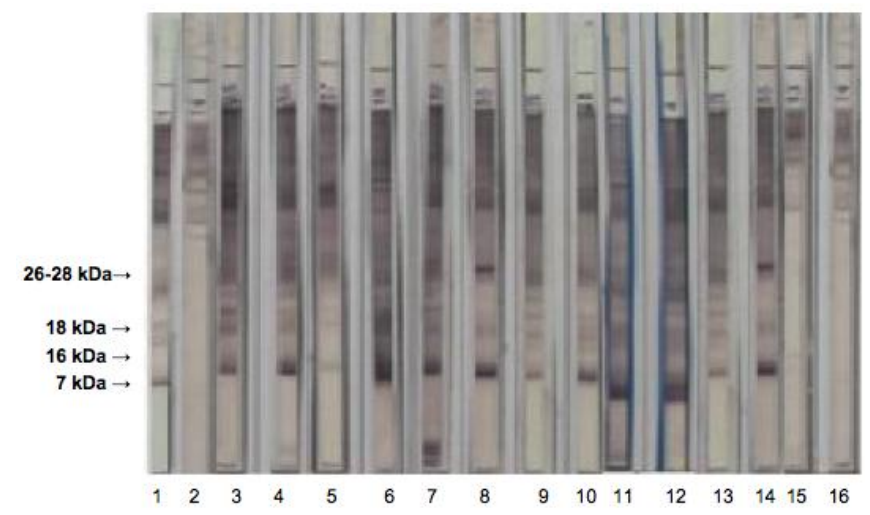

Figure 3. Western blot analysis of 12 patients sera using Echinococcosis WB IgG kit. The lines represent: 1positive E. multilocularis control, 2-negative control, 314 sera with confirmed $\mathrm{AE}$ patients preoperation (positive $16 \mathrm{kDA}-18 \mathrm{kDA}$ bands), 15-16 AE patients postoperation. (Presence on the strip of a band at 7 and/or 26-28 kDa; diagnosis of the genus Echinococcus and 16-18 kDa; diagnosis of the species Echinococcus multilocularis)

No mortalities were recorded except for one patient who had massive pulmonary emboli despite appropriate precautions. That patient had undergone left hepatectomy and cholecystectomy for a $12 \mathrm{~cm}$ large left hepatic AE but died on postoperative day 9 in the intensive care unit. All other complications were managed successfully with re-operation $(n=4)$ or conservative treatment $(n=2)$.

Out of 4 patients who were diagnosed with metastatic disease, complications were observed in 3 patients and managed successfully $(n=1 \quad$ conservative, $n=2$ reoperation). Follow-up radiological evaluation did not show any case of new or recurrent hepatic lesion.

\section{DISCUSSION}

The current study shows that long-term favorable outcomes can be achieved by complete surgical resection followed by chemotherapy with albendazole even in advanced hepatic AE cases. Highly advanced cases, such as those in which adjacent organs are involved and those in which metastasis are identified, can be treated with complete hepatic resections with acceptable complication rates.

$\mathrm{AE}$ is found in the northern hemisphere and is a potentially fatal disease. The infectious eggs of the parasite are transmitted via feces of foxes. The liver is almost always affected ${ }^{4,5}$. Recently published reports have demonstrated rural-tourban regionally expanding endemic areas in regards to E. multilocularis $3,9,10$. If this trend continues, it is possible that human $\mathrm{AE}$ will become an emergent zoonosis in some regions of Europe and Eurasia. Improvements in diagnostic and treatment approaches are being investigated ${ }^{1}$.

$\mathrm{AE}$ is recognized by intrahepatic tumor-like multi-vesicular primary lesions with its infiltrating features. Early diagnosis of $\mathrm{AE}$ is made by considering characteristic symptoms, imaging techniques, serology, histopathological examination or molecular analysis of biopsied material $4,9,11$. Asymptomatic chronic E. multilocularis infection lasting up to 15 years represents the greatest proportion of infected cases. Diagnosis of AE is often difficult and can sometimes be only possible in the later stages of the disease. Recently developed and 
improved serological tests for $\mathrm{AE}$ have been shown to be reliable but they are rarely available in most urban areas. Consequently, failure to diagnose $\mathrm{AE}$ or its misdiagnosis leads to presentation in advanced stages, making treatment challenging and prognosis poor ${ }^{11,12}$. Symptoms depend on the involved organs. In metastatic cases patients may be referred to other clinics based on the metastasis related symptoms. In this series, abdominal pain was the most common symptom with jaundice. Patients were referred to our clinic at least two years after the symptoms began. None of them could be diagnosed in stage 1 . In one patient who had brain metastasis; the only symptoms were epileptic attacks and headache.

Imaging techniques of hepatic involvement by AE commonly reveal an ill-defined lesion of the liver parenchyma and contrast computer tomography (CT) and MRI are considered to clearly demonstrate infiltrative structure and extension of the parasitic tumor to adjacent structures 3,13,14. According to current treatment guidelines, cure can be achieved by surgical treatment once the parasitic mass is predicted as resectable $3,4,6,11$. In advanced cases, organs neighboring the liver can be infiltrated by the organisms, whereas distant organs such as lungs and brain can be affected hematogenously. For liver cases where resection is not feasible, or complications develop, a liver transplant can be a lifesaver. Liver transplantation, as treatment option for AE cases, is technically difficult because of the history of prior surgery, interventional radiological procedures, and mass size $\mathrm{s}^{3,15}$. Moray et al. reported two cases of advanced AE, which invaded both lobes and the inferior vena cava. Both cases were treated successfully with liver transplantation. The authors suggested transplantation as a lifesaving treatment of choice in patients who did not have any other medical or surgical options ${ }^{16}$. Ayifuhan et al analyzed 50 cases of hepatic AE who were treated with radical or conservative surgery. In their retrospective analysis, mortality and recurrence were significantly higher in a palliative group. They concluded that radical resection appears to be best treatment of hepatic $\mathrm{AE}$ and palliative operation may cause a series of severe complications leading to death ${ }^{17}$.

It has been previously reported that, if left untreated $>95 \%$ of $\mathrm{AE}$ patients will die within 10 years following diagnosis ${ }^{18}$. As described here, surgery can be used even for late stage $\mathrm{AE}$ cases, but this attempt may be problematic because of the difficulty in removing all of the parasitic lesions. To improve survival for patients with non-resectable lesions or for which complete resection is not feasible, chemotherapy should be used in combination with surgery. Due to high and well-kown efficacy against AE, albendazole should be used before surgical procedure, together with regular patient follow-up posttreatment $10,11,19,20$. Despite remarkable improvement of long-term patient survival after the introduction of anti-helmintic drug treatment, this therapeutic modality proved to be mostly parasitostatic. Therefore, surgical resection represents the therapy of choice for patients with operable lesions of $\mathrm{AE}^{3,11,21}$.

Metastatic AE is a special challenge. The lesions may spread to the thyroid, bone, vertebra, scrotum, spleen, ovary, heart, kidney, peritoneum, lymph nodes, rectus muscle, knee, lacrimal sac and occasionally the nervous system $^{22,23}$. Cerebral occurrence in $\mathrm{AE}$ is approximately $1 \%$, and considered to be fatal. Treatment involves chemotherapy with benzimidazole derivatives (albendazole, mebendazole) and surgery for accessible lesions. Cure is achieved only if the lesion is completely resected followed by chemotherapy that may prolong the patient's survival time. We had four cases of metastatic AE who were all treated successfully with resection of the invaded organ. Decrease in antibody levels was observed in all cases where curative resections 
could be performed. In these patients, antibody levels began to decrease at 6,12 and 18 months after surgery in 4, 6, and 1 patients, respectively. Only one patient had WB seropositivity for $\mathrm{AE}$ after discharge with serological tests by WB. As shown in our series, albendazole treatment combined with complete curative resections may be responsible for satisfying long-term outcomes and sustained low antibody levels.

As a conclusion, this report represents our surgical experience in advanced AE cases. Based on literature and our findings, we suggest that early diagnosis and radical resection combined with antihelmintic drug therapy is the life saving and associated with favorable long-term outcomes in $\mathrm{AE}$ even in advanced cases. Yet; there is need for more, larger and prospective studies.

\section{Acknowledgments}

The authors declare that they have no conflicts of interest.

- The authors have no conflicts of interest or financial ties to disclose.

-Presented as oral presentation in Turkish Hepatobiliary Surgery Congress, 2013.

Declaration of Conflicting Interests: The authors declare that they have no conflict of interest.

Financial Disclosure: No financial support was received.

\section{REFERENCES}

1. Craig P. Echinococcus multilocularis. Curr Opin Infect Dis. 2003; 16:437-44.

2. Miman 0, Yazar S. Alveolar echinococcosis in Turkey: In the light of the literature.Turkiye Parazitol Derg. 2012; 36: 116-20.

3. Atanasov G, Benckert C, Thelen A, et al. Alveolar echinococcosis-spreading disease challenging clinicians: A case report and literature review.World J Gastroenterol. 2013; 19: 4257-61.

4. Buttenschoen K, Kern P, Reuter S, et al. Hepatic infestation of Echinococcus multilocularis with extension to regional lymph nodes. Langenbecks Arch Surg. 2009; 394: 699-704.

5. Ishizu H, Uchino J, Sato N, et al. Effect of albendazole on recurrent and residual alveolar echinococcosis of the liver after surgery. Hepatology. 1997; 25: 528-31.

6. Ammann RW, Eckert J. Cestodes. Echinococcus. Gastroenterol Clin North Am. 1996; 25: 655-89.

7. Rutkauskas S, Gedrimas V, Pundzius J, et al. Clinical and anatomical basis for the classification of the structural parts of liver. Medicina (Kaunas). 2006; 42: 98-106.

8. Dindo D, Demartines N, Clavien PA. Classification of surgical complications: a new proposal with evaluation in a cohort of 6336 patients and results of a survey. Ann Surg. 2004; 240: 205-13.

9. Craig PS, Deshan L, MacPherson CN, et al. A large focus of alveolar echinococcosis in central China. Lancet. 1992; 340: 826-31.

10. Moro P, Schantz PM. Echinococcosis: a review. Int J Infect Dis. 2009; 13: 125-33.

11. Kawamura N, Kamiyama T, Sato N, et al. Long-term results of hepatectomy for patients with alveolar echinococcosis: a single-center experience. J Am Coll Surg. 2011 May; 212: 804-12

12. Tiaoying L, Jiamin Q, Wen $Y$, et al. Echinococcosis in Tibetan populations, western Sichuan Province, China. Emerg Infect Dis. 2005; 11:1866-73.

13. Czermak BV, Akhan O, Hiemetzberger R, et al. Echinococcosis of the liver. Abdom Imaging. 2008; 33: 133-143.

14. Maier W. Computed tomographic diagnosis of Echinococcus alveolaris. Hepatogastroenterology. 1983; 30:83-5.

15. Hatipoglu S, Bulbuloglu B, Piskin T, et al. Living donor liver transplantation for alveolar echinococcus is a difficult procedure. Transplant Proc. 2013; 45:1028-30.

16. Moray G, Shahbazov R, Sevmis S, et al. Liver transplantation in management of alveolar echinococcosis: two case reports. Transplant Proc. 2009; 41: 2936-8.

17. Ayifuhan A, Tuerganaili A, Jun C, et al. Surgical treatment for hepatic alveolar echinococcosis: report of 50 cases. Hepatogastroenterology. 2012; 59: 790-3.

18. Brunetti E, Kern P, Vuitton DA. Expert consensus for the diagnosis and treatment of cystic and alveolar echinococcosis in humans. Acta Trop. 2010; 114:1-16.

19. Brunetti E, Maiocchi L, Garlaschelli AL, et al. Overview of therapeutic options for cystic echinococcosis. Parassitologia. 2004; 46:53-5. 
20. McManus DP, Li Z, Yang S, et al. Case studies emphasizing the difficulties in the diagnosis and management of alveolar echinococcosis in rural China. Parasit Vectors. 2011; 4:196.

21. Kern P. Clinical features and treatment of alveolar echinococcosis. Curr Opin Infect Dis. 2010; 23:505-12.
22. Ozdemir NG, Kurt A, Binici DN, et al. Echinococcus alveolaris: presenting as a cerebral metastasis. Turk Neurosurg. 2012; 22: 448-51.

23. Algros MP, Majo F, Bresson-Hadni $S$, et al. Intracerebral alveolar echinococcosis. Infection. 2003; 31: 63-5. 